\title{
DETERMINAN PERTUMBUHAN EKONOMI DI NEGARA OKI (STUDI KASUS: 10 NEGARA ANGGOTA OKI)
}

\author{
Fani Monada Essa Putri \\ Sekolah Tinggi Ekonomi Syariah Tunas Palapa \\ fanimonada30@gmail.com
}

\begin{abstract}
Abstret Economic growth is a leading indicator in measuring a country's wellbeing. Economic growth in most countries in the world has increased so far. Therefore, the purpose of this study is to find out the factors that affect economic growth in OIC member countries. The study also aims to determine economic growth in 10 OIC member countries. The results showed that export variables, government spending, human development indices had a significant positive effect on economic growth in the 10 OIC member countries. While the population growth variable, the labor force variable has a significant negative effect on economic growth in the 10 OIC member countries. The variables of the democracy index have no effect on economic growth in the $10 \mathrm{OIC}$ member countries.
\end{abstract}

Keywords Economic Growth, Exports, Government Expenditure, Population Growth, HDI, Labor Force, Democracy Index.

\section{PENDAHULUAN}

Dewasa ini pertumbuhan ekonomi adalah hal yang sangat penting karena perekonomian suatu negara ataupun wilayah dilihat dari pertumbuhan ekonomi. Tumbuh kembangnya perekonomian yaitu menilai kinerja suatu negara terutama dalam hal menganalisis pembangunan. Pertumbuhan ekonomi merupakan cerminan dari perkembangan disuatu wilayah ataupun negara (Sukirno, 2006). Todaro (2000) mengemukakan bawasannya tersedianya produk ataupun jasa kepada warganya sebagai wujud pertumbuhan ekonomi yang lebih baik.

Organisasi kerja sama Islam merupakan organisasi terbesar setelah PBB yang beranggotakan 57 negara. OKI beranggotakan 57 negara dengan penduduk mayoritas muslim di kawasan Asia dan Afrika. Akan tetapi fakta empiris menunjukkan bahwa negara-negara Muslim (penduduk mayoritas Muslim) relatif tertinggal dalam hal kinerja ekonominya (Wibowo 2020). Tidak hanya itu, pertumbuhan ekonomi di negara OKI melambat menjadi 3,8 \% sejak tahun 2017 (OIC Economic Outlook, 2017).

Beberapa negara OKI diantaranya ialah Indonesia, Nigeria, Arab Saudi, Mesir, Malaysia, Pakistan, Uni Arab Emiret, Bangladesh, Turki serta Iran ialah negara dengan jumlah penduduk tertinggi di negara anggota OKI. Akan tetapi jumlah penduduk yang tinggi berbanding terbalik dengan GDP yang ada di masing-masing negara. GDP yang ada di tiap masing-masing negara menunjukkan tren yang sangat berfluktuatif disetiap tahunnya. 


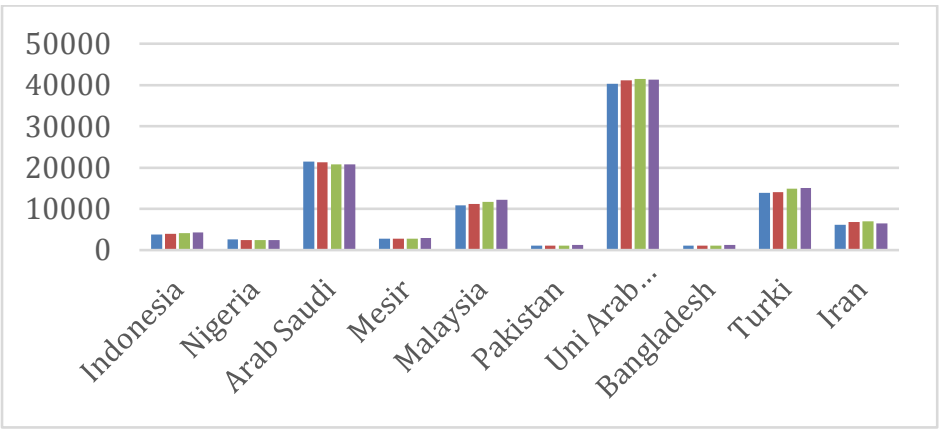

\section{Gambar 1.1. Perkembangan GDP Per Kapita di 10 Negara Anggota OKI tahun 2015-2018}

Sumber: World Bank, 2018

Berdasarkan Gambar 1.1, dapat dilihat perkembangan GDP di 10 negara anggota OKI. Beberapa tahun terakhir tren menunjukkan perkembangan yang sangat berfluktuatif dari tahun ketahun. Dari kesepuluh negara anggota OKI Uni Arab Emiret dengan GDP tertinggi. Hal ini mengindiksikan bahwa pertumbuhan ekonomi di Negara Uni Arab Emiret sangat baik.

Selain itu adanya hubungan antara ekspor dan pertumbuhan ekonomi. Teori North Douglass (1964) yang merupakan pengembangan dari teori sebelumnya yang mana dalam teori tersebut dijelaskan bahwa sektor ekspor mampu menekankan laju pertumbuhan ekonomi. Manfaat dari ekspor diantaranya selain menambah devisa bagi negara juga membuat produk yang dihasilkan bisa bersaing diranah internasional hal ini menjadi keuntungan bagi suatu negara karena secara tidak langsung meningkatnya rasa percaya publik sehingga mendorong laju pertumbuhan ekonomi.

Selain itu Teori pengeluaran pemerintah dikemukakan yang dikemukakan oleh Keynesian Cross yang mana dijelaskan bahwa pengeluaran pemerintah berdampak pada pertumbuhan ekonomi yang diukur melalui pendapatan dan tingkat output (Mankiw, 2003). Erat kaitannya antara dalam pertumbuhan penduduk dengan pertumbuhan ekonomi. Malthus (2008) yang mengemukakan bahwa adanya hubungan antara pertumbuhan penduduk dengan pertumbuhan ekonomi yang mana pertumbuhan penduduk dengan pertumbuhan ekonomi memiliki pola yang geometris.

Ranis Stewart dan Ramirez menjelaskan bahwa pembangunan manusia dianggap sebagai tujuan aktivitas manusia dan pertumbuhan ekonomi, sekaligus merupakan instrumen strategis dalam memajukannya. Di satu sisi peningkatan tingkat pembangunan manusia mengarah pada peningkatan peluang pertumbuhan ekonomi (Elistia and Syahzuni, 2018).

Yakubu and Benedict N. Akanegbu (2018) mengungkapkan bahwa tenaga kerja merupakan aset bagi negara yang mana diukur dengan banyaknya tingkat partisipasi angkatan kerja. Selain itu penelitian ini menemukan bahwa partisipasi angkatan kerja merupakan faktor pendorong yang sangat penting bagi pertumbuhan ekonomi. Oleh karena itu penelitian ini ingin mengetahui pengaruh ekspor, government expenditure, pertumbuhan penduduk, human development index, angkatan kerja dan indeks demokrasi terhadap pertumbuhan ekonomi di 10 negara anggota OKI pada tahun 2009-2018. 


\section{LANDASAN TEORI}

\section{A. 1. Pertumbuhan Ekonomi}

Teori Pertumbuhan Klasik

Pemikiran ekonomi dibedakan menjadi dua golongan yaitu kaum klasik dan kaum Neo-klasik. Tokoh-tokoh ekonom klasik diantaranya adalah Adam Smith, Ddavid Ricardo, Malthus. Secara umum pendapat kaum klasik mengarahkan kepada perekonomian yang terditi atas dua sektor yaitu produsen dan konsumen dan perekonomian diserahkan kepada mekanisme pasar (Sadono Sukirno 2006).

Adam Smith ddalam bukunya Bukunya berisikan tentang perkembangan ekonomi disuatu negara. Menurut Smith ada beberapa faktor salah satunya mekanisme pasar yang mempengaruhi pembangunan suatu negara. Smith mengemukakan bahwa perkembangan didasarkan pada penduduk sebagai faktor pendorong bagi tumbuh kembangnya perekonomian sehingga hal tersebut akan berdampak secara komulatif (Sukirno Sadono, Teori Neo-Klasik

Teori kaum Neo-klasik dicetuskan oleh Solow dan Abramovits mereka berpendapat bahwa pertumbuhan ekonomi dari segi penawaran. Perekembangan perekonomian didasarkan pada tingginya produksi disuatu negara dan berkembangnya teknologi sehingga hal ini mampu mendorong tenaga kerja yang handal (Todaro, 2010)

\section{Ekspor}

North Douglass (1964) mengemukakan teori yang disebut dengan basis ekonomi yang mana teori ini pengembangan dari teori sebelumnya. Dalam teori tersebut dijelaskan bahwa sektor ekspor mampu menekankan laju pertumbuhan ekonomi. Ekspor memberikan kontribusi bagi pertumbuhan ekonomi nasional maupun internasional. Menurut Apridar (2009) hal yang memegang peranan penting ialah ekspor karena ekspor menjadi penggerak pertumbuhan suatu wilayah atau negara.

\section{Government Expenditure}

Teori Keynesian Cross yang mana dijelaskan bahwa pengeluaran pemerintah berdampak pada pertumbuhan ekonomi yang diukur melalui pendapatan dan tingkat output (Mankiw, 2003). Pemerintah berperan besar dalam meningkatkan pertumbuhan ekonomi. Bila pengeluaran pemerintah tidak dialokasikan dengan tepat maka akan menghambat pertumbuhan ekonomi.

Ketika rendahnya pengeluaran pemerintah maka akan merugikan bagi pertumbuhan ekonomi. Sehingga ketika pengeluaran pemerintah sesuai porsinya akan meningkatkan pertumbuhan sedangkan ketika pengeluaran pemerintah cenderung tinggi akan menjadi terhambatnya pertumbuhan ekonomi. Untuk itu peranan pemerintah memberikan dampak yang positif bagi pertumbuhan ekonomi (Eliza, 2015).

\section{Pertumbuhan Penduduk}

Teori Malthus (1798) mengatakan adanya hubungan yang geometris terkait pertumbuhan ekonomi dan pertumbuhan populasi. Khan (2020) dalam penelitiannya mencoba untuk mengetahui pengaruh teori Malthusian. Hasilnya ialah pertumbuhan penduduk memiliki pengaruh positif pada pertumbuhan ekonomi. Hal ini dilihat dari hubungan jangka pendek maupun jangka panjang. Meskipun hubungan antara keduanya masih menjadi perbincangan dikalangan Ekonom, akan tetapi pertumbuhan penduduk memiliki peran penting dalam pertumbuhan ekonomi dan bahkan mungkin berkontribusi pada peningkatan pertumbuhan output per kapita dalam beberapa kasus (Wesley, E., \& Peterson, 2017). 
Adam Smith (1776) berargumen bahwa salah satu sumber yang sangat penting bagi negara ialah kenaikan jumlah penduduknya. Senada dengan Smith, Mankiw (2010) sependapat dengan model Kramerian bahwa pertumbuhan populasi didunia merupakan pendorong untuk memajukan kemakmuran ekonomi. Jika lebih banyak orang, maka akan berpotensi untuk memajukan kemajuan teknologi

\section{Human Development Index}

Selain itu berangkat dari UNDP yang menujukkan bahwa ketika pembangunan manusia baik maka berdampak pada pertumbuhan yang baik dan tentunya ratanya pendapatan (UNDP, 1990). Perlu diketahui bahwa faktor penting lainnya dalam pertumbuhan ekonomi ialah pembangunan manusia. Ketika sumber daya manusia unggul dan mempunyai kualitas maka menjadikan pendorong bagi aktivitas perekonomian (Tjiptoherijanto P, 1999). Ranis (2004) berpendapat bahwa kontribusi pembangunan manusia yang berkualitas berdampak pada pertumbuhan ekonomi dan nantinya akan mengarah ke pembangunan.

Menurut UNDP (1990) mengartikan bahwa secara esensial dalam pembangunan manusia dapat merasakan standar hidup layak, pengetahuan cukup dan kesehatan yang memadai. UNDP membagi status pembangunan manusia suatu negara berdasarkan beberapa kategori yaitu:
a) Ukuran sangat tinggi $(0.800-1.000)$
b) Ukuran tinggi (0.700-0.799)
c) Ukuran menengah (0.555-0.699) dan
d) Ukuran Rendah (0.350-0.554)

\section{Angkatan Kerja}

Berangkat dari hal tersebut hubungan antara angkatan kerja dan pertumbuhan ekonomi seperti yang dikemukakan oleh Todaro (2003) pertumbuhan Angkatan Kerja (AK) merupakan salah satu faktor positif yang memacu pertumbuhan ekonomi. Jumlah tenaga kerja yang lebih besar berarti akan menambah tingkat produksi yang nantinya akan meningkatkan pertumbuhan ekonomi.

Secara sederhana dapat dikatakan tingkat partisipasi angkatan kerja adalah proporsi penduduk usia kerja yang bekerja atau aktif mencari pekerjaan. Tarif ini merupakan ukuran pasar tenaga kerja yang penting karena mewakili jumlah relatif sumber daya tenaga kerja yang tersedia untuk produksi barang dan jasa (Hipple, 2016).

\section{Indeks Demokrasi}

Held D (2007) mendefinisikan bahwa demokrasi yaitu kebebasan, dan keadilan. Demokrasi adalah keturutsertaan rakyat atau masyarakat dalam memilih dengan cara bebas dan tentunya dengan unsur keadilan. Demokrasi menurut Held yaitu bagaimana menangani permasalahan serta isu-isu sehingga dapat diselesaikan.

Berangkat dari Teori Seymour Lipset (1963) yang mana dalam teorinya mengemukakan bahawa demokrasi memiliki hubungan positif terhadap pertumbuhan ekonomi apabila memenuhi beberapa hal: (1) Demokrasi didukung oleh kebijakankebijakan yang memajukan ekonomi (2) didukung oleh kinerja aparatur yang baik. (3) Demokrasi yang diterapkan tidak hanya pada tingkat prosedural tetapi mampu ditransformasikan kedalam pemerintahan yang baik. 


\section{METODOLOGI PENELITIAN}

Penelitian ini menggunakan variabel independent yaitu ekspor, government expenditure, pertumbuhan penduduk, human development index, angkatan kerja dan indeks demokrasi. Sedangkan variabel dependen yaitu GDP. Jenis data yang digunakan dalam penelitian ini adalah data sekunder, dimana data sekunder mengacu pada informasi yang dikumpulkan dari berbagai sumber yang sudah ada (Sekaran, 2017). Adapun variabel independen yang digunakan yaitu GDP yang bersumber dari (https://data.worldbank.org/). Sedangkan variabel independen yang digunakan meliputi ekspor, government expenditure, pertumbuhan penduduk, angkatan kerja bersumber dari (https://data.worldbank.org/). Sedangkan human development index diperoleh dari UNDP dan indeks demokrasi berumber dari Economic Intelligence Unit.

Penelitian ini menggunakan alat analisis regresi data panel. Data panel adalah data yang diperoleh dari data cross section yang diobservasi berulang pada unit objek yang sama pada waktu yang berbeda. Dengan demikian, akan diperoleh gambaran tentang perilaku beberapa objek tersebut selama beberapa periode waktu (Tarigan, 2012). Uji regresi data panel ini digunakan untuk mengetahui hubungan antara variabel independen yang terdiri dari ekspor (X1), government expenditure (X2), pertumbuhan penduduk (X3), dan human development index (X4), angkatan kerja (X5), dan indeks demokrasi (X6) terhadap Pertumbuhan Ekonomi di 10 negara anggota OKI yang diproksikan dengan GDP (Y). Berdasarkan rumusan masalah dan dilandasi dengan kerangka teori dan penelitian terdahulu , maka penelitian ini dapat dimodelkan sebagai berikut:

GDPit $=\alpha 0+\beta_{1}$ EXPORTit $+\beta_{2}$ GOVit $+\beta_{3}$ PGit $+\beta_{4}$ HDIit $+\beta_{5}$ LFit $+\beta_{6}$ DMit + cit.

Keterangan:

GDP : GDP per kapita

EXPORT: ekspor

GOV : government expenditure

PG : pertumbuhan penduduk

HDI : human development index

LF : angkatan kerja

DM : demokrasi

$\alpha \quad$ : konstanta (intercept)

$\beta_{1,2} \quad$ : parameter (slope koefisien)

$\varepsilon \quad$ : error

n : banyaknya negara

t : banyaknya waktu

Model data panel diatas diestimasi menggunakan metode Common Effect, Fixed Effect dan Random Effect. Untuk menganalisis data panel diperlukan uji spesifikasi model yang tepat untuk menggambarkan data. Adapun uji spesifikasi model yang dimaksud ialah Uji Chow dan Uji Hausman.

\section{HASIL PENELITIAN}

\section{A. Uji Chow (Likelihood test ratio)}

Uji Chow test merupakan uji yang memilih model mana yang akan peneliti gunakan. Dalam uji Chow pemilihan model yang terpilih antara Common Effect Model dengan Fixed Effect Model (FEM). Dengan hipotesis sebagai berikut:

HO : Model common effect

H1 : Model fixed effect 
Apabila nilai probabilitas (Prob.) untuk cross section $\mathrm{F}>\alpha=5 \%$ maka $\mathrm{H} 0$ diterima dan H1 ditolak dengan kata lain model yang terpilih adalah model common effect, tetapi apabila nilai probabilitas (Prob.) untuk cross section $\mathrm{F}<\alpha=5 \%$ maka $\mathrm{H} 0$ ditolak dan $\mathrm{H} 1$ diterima dengan kata lain model yang terpilih adalah model fixed effect

Tabel 4. 1 Hasil Uji Chow

\begin{tabular}{|l|l|l|}
\hline Effect Test & Statistic & Prob. \\
\hline Cross-section F & 576.630122 & 0.0000 \\
\hline Cross-section Chi-square & 413.966520 & 0.0000 \\
\hline
\end{tabular}

Sumber: Data diolah peneliti, 2021

Dari hasil uji chow di atas dapat dilihat dari nilai probabilitas yaitu sebesar 0.0000 artinya lebih kecil dari alpha 0.05. Maka disimpulkan bahwa dalam uji ini model Fixed Effect yang tepat daripada model Common Effect.

\section{B. Hasil Uji Hausman}

Uji Hausman ialah pengujian statistik untuk memilih model yang tepat untuk digunakan antara Fixed Effect Model (FEM) atau Random Effect Model (REM). Dengan hipotesis sebagai berikut:

$\mathrm{H} 0$

H1
: Random Effect Model

: Fixed Effect Model

Tabel 4. 2 Uji Hausman

\begin{tabular}{|l|l|l|}
\hline Test Summary & $\begin{array}{l}\text { Chi-Sq } \\
\text { Statistic }\end{array}$ & Prob. \\
\hline Cross-section random & 13.178887 & 0.0403 \\
\hline
\end{tabular}

Berdasarkan hasil estimasi di atas, diperoleh nilai probabilitas 0.0403 artinya lebih kecil dari alpha 0.05. maka H0 ditolak dan H1 diterima. Sehingga dapat disimpulkan bahwa penggunaan pilihan model yang terbaik adalah Fixed Effect Model (FEM).

Dari hasil serangkaian pengujian didapatkan hasil bahwa dari uji chow test terpilih Fixed Effect Model (FEM) bukan Common Effect Model (CEM), dan dari uji hausman test yang terpilih juga model Fixed Effect Model (FEM) bukan Random Effect Model (REM).

Dari masing-masing pengujian yang telah dilakukan di atas menghasilkan model yang sama. Maka pada tahap selanjutnya tidak perlu melakukan pengujian Uji Langrage Multiplier (LM-Test). Sehingga model yang digunakan dalam penelitian ini adalah Fixed Effect Model (FEM).

\section{Hasil Uji FEM}

Model regresi yang tepat untuk penelitian ini adalah regresi panel dengan pendekatan yang terpilih adalah Fixed Effect Model (FEM). Pada penelitian ini digunakan nilai signifikansi alpha 5\% (0.05). Hasil pengujian statistik diperoleh nilai probabilitas sebesar $0.0000<0.05$ dengan tingkat signifikansi alpha 5\%. Sehingga H0 ditolak dan menerima $\mathrm{H} 1$ atau alternatif. Berikut tabel hasil pengujian Fixed Effect Model (FEM): 
Tabel 4. 3 Uji Fixed Effect

\begin{tabular}{|l|l|l|l|l|}
\hline Variabel & Coeff. & t-Stat. & Prob. & Keterangan \\
\hline LOG (EKS) & 1240.014 & 1.922999 & 0.0579 & Signifikan \\
\hline LOG(GOV) & 2388.179 & 3.116663 & 0.0025 & Signifikan \\
\hline PG & -208.8017 & -2.703628 & 0.0083 & Signifikan \\
\hline HDI & 34884.15 & 4.974655 & 0.0000 & Signifikan \\
\hline LF & -0.000150 & -3.936309 & 0.0002 & Signifikan \\
\hline ID & & & & Tidak \\
& 64.43721 & 0.225641 & 0.8220 & Signifikan \\
\hline Adj. R-square & & 0.995611 \\
\hline F-statistic & & 1497.999 \\
\hline Prob. F-statistic & & 0.0000 \\
\hline
\end{tabular}

Sumber: Data diolah peneliti, 2021

Berdasarkan Tabel di atas di ketahui bahwa slope variabel EKS sebesar 1240.014 variabel GOV sebesar 2388.179 variabel PG sebesar -208.8017 sedangkan HDI sebesar 34884.15 LF sebesar -0.000150 kemudian ID sebesar 64.43721 Sementara nilai P-value untuk variabel EKS yaitu 0.0579 untuk variabel GOV 0.0025 dan untuk variabel PG 0.0083 sementara untuk variabel HDI sebesar 0.0000 variabel LF sebesar 0.0002 dan DM sebesar 0.8220. Jika variabel independen bernilai nol maka variabel dependen (GDP) adalah sebesar -98214.95 dengan error term sebesar 21313.77 Nilai R-squared sebesar 0,995611 atau 99\% dan Prob (F-statistics) sebesar 0,000000. Maka model estimasi dari common atau pooled least square diketahui sebagai berikut :

GDPit=-98214.95it+1240.014it+2388.179it-208.8017+34884.15 0.000150+64.43721it

Ket :*signifikan $\alpha=0,05(5 \%)$

Berdasarkan hasil dari estimasi diatas diketahui bahwa model regresi data panel metode Common Effect secara statistik variabel EKS, GOV, PG, HDI, LF merupakan lima variabel independen yang berpengaruh secara signifikan terhadap variabel GDP (Y). Sedangkan variabel ID mempunyai nilai probabilitas sebesar 0.8220 dimana lebih besar dari alpha > dari 0,05.

\section{Uji Statistik F}

Uji $\mathrm{F}$ dilakukan untuk melihat ada atau tidaknya pengaruh bersama-sama (simultan) yaitu Ekspor (EKS), Government Expenditure (GOV), Pertumbuhan Penduduk (PG), Human Development Index (HDI), Angkatan Kerja (LF) dan Indeks Demokrasi (ID).

Berdasarkan hasil regresi pada tabel 4.5 dengan menggunakan model Fixed Effect maka diperoleh nilai F sebesar 1497.999 dengan probabilitas sebesar 0.000000 sehingga dapat kita simpulkan bahwa seluruh variabel Independen secara bersama-sama (simultan) berpengaruh secara signifikan terhadap variabel dependen

\section{Koefisien Determinasi (R2)}

Berdasarkan hasil regresi yang ditunjukan pada tabel 4.5 di atas, maka variabel Ekspor (EKS), Government Expenditure (GOV), Pertumbuhan Penduduk (PG), Human Development Index (HDI), Angkatan Kerja (LF) dan Indeks Demokrasi (ID) diperoleh nilai R2 atau Adjusted R-squared sebesar Artinya bahwa variasi dari variabel independen mampu menjelaskan sebesar 99\% Sedangkan sisanya yaitu $1 \%$ dijelaskan oleh variabelvariabel diluar penelitian ini. 


\section{4. $\quad$ Uji t (Uji Parsial)}

Berdasarkan tabel 4.5 variabel Ekspor (EKS) sebesar 1240.014 dengan probabilitas 0.0579 signifikan pada ó 5\%. Maka dijelaskan bahwa variabel ekspor berpengaruh positif signifikan terhadap pertumbuhan ekonomi di 10 negara anggota OKI. Government Expenditure (GOV) sebesar 2388.179 dengan probabilitas 0.0025 signifikan pada ó 5\%. Maka dijelaskan bahwa variabel Government Expenditure berpengaruh positif signifikan terhadap pertumbuhan ekonomi di 10 negara anggota OKI. Variabel ketiga adalah pertumbuhan penduduk yang mana (PG) sebesar -208.8017 dengan probabilitas 0.0083 signifikan pada $\alpha$ 5\% yang artinya pertumbuhan penduduk berpengaruh negatif signifikan terhadap pertumbuhan ekonomi di 10 negara anggota OKI. Variabel HDI (HDI) sebesar 34884.15 dengan probabilitas 0.0000 signifikan pada $\alpha$ s\% artinya berpengaruh positif signifikan terhadap pertumbuhan ekonomi di 10 negara anggota OKI. Variabel Angkatan kerja (LF) sebesar -0000150 dengan probabilitas 0.0002 signifikan pada $\alpha$ 5\% artinya angkatan kerja berpengaruh negatif signifikan terhadap pertumbuhan ekonomi di 10 negara anggota OKI. Variabel terakhir yaitu indeks demokrasi (ID) sebesar 64.43721 dengan probabilitas $0.8220>$ dari á 5\% maka variabel indeks demokrasi tidak berpengaruh terhadap pertumbuhan ekonomi di 10 negara anggota OKI.

\section{PEMBAHASAN}

Variabel ekspor berpengaruh positif terhadap pertumbuhan ekonomi di 10 negara anggota OKI. Ekspor memiliki nilai koefisien sebesar 1240.014 dengan nilai probabilitas sebesar 0.0579 signifikan pada ó 5\%. Maka dapat dijelaskan bahwa ekspor berpengaruh terhadap positif signifikan terhadap pertumbuhan ekonomi di 10 negara anggota OKI. Hal ini berarti jika terjadi kenaikan nilai ekspor maka pertumbuhan ekonomi (GDP) juga akan naik.

Variabel government expenditure. Pengeluaran pemerintah memiliki hubungan positif terhadap pertumbuhan ekonomi. Government expenditure memiliki nilai koefisien sebesar 2388.179 dengan probabilitas 0.0025 signifikan pada ó 5\%. Maka dijelaskan bahwa variabel Government Expenditure berpengaruh positif signifikan terhadap pertumbuhan ekonomi (GDP) di 10 negara anggota OKI.

Berdasarkan uji fix effect model hasil yang didapat dalam penelitian ini menunjukkan bahwasannya pertumbuhan penduduk yang mana sebesar -208.8017 dengan probabilitas 0.0083 signifikan pada $\alpha$ $5 \%$. Hal ini sejalan dengan teori Malthus (1798) menjelaskan bahwa ketika pertumbuhan penduduk meningkat maka hal tersebut berdampak pada kelangkaan sumber daya dan faktor lainnya yang nantinya akan mengakibatkan terhambatnya pertumbuhan ekonomi.

Variabel human development index sebesar 34884.15 dengan probabilitas 0.0000 signifikan pada $\alpha$ $5 \%$ artinya berpengaruh positif signifikan terhadap pertumbuhan ekonomi di 10 negara anggota OKI. Artinya apabila terjadi kenaikan human development index maka pertumbuhan ekonomi (GDP) akan naik.

Berdasarkan uji fix effect model variabel Angkatan kerja (LF) sebesar -0000150 dengan probabilitas 0.0002 signifikan pada $\alpha$ 5\% artinya angkatan kerja berpengaruh negatif signifikan terhadap pertumbuhan ekonomi di 10 negara anggota OKI. Menurut Todaro (2003) pertumbuhan Angkatan Kerja (AK) merupakan salah satu faktor positif yang memacu pertumbuhan ekonomi. Jumlah tenaga kerja yang lebih besar berarti akan menambah tingkat produksi yang nantinya akan meningkatkan pertumbuhan ekonomi. Dari penelitian Ariusni (2019), salah satu penyebabnya ialah peran pemeintah. Dalam hal ini pemerintah belum mampu memenuhi kebutuhan lapangan kerja yang diharapkan. 
Indeks demokrasi (ID) sebesar 64.43721 dengan probabilitas $0.8220>$ dari ó 5\% maka variabel indeks demokrasi tidak berpengaruh terhadap pertumbuhan ekonomi di 10 negara anggota OKI. Maka hipotesis ditolak. Teori Seymour Lipset (1963) mengemukakan bahawa demokrasi memiliki hubungan positif terhadap pertumbuhan ekonomi apabila memenuhi beberapa hal: (1) Demokrasi didukung oleh kebijakankebijakan yang memajukan ekonomi (2) didukung oleh kinerja aparatur yang baik. (3) Demokrasi yang diterapkan tidak hanya pada tingkat prosedural tetapi mampu ditransformasikan kedalam pemerintahan yang baik.

\section{KESIMPULAN}

Berdasarkan hasil uji model fixed effect bahwa variabel ekspor berpengaruh positif signifikan terhadap pertumbuhan ekonomi di 10 negara anggota OKI.. Berdasarkan hasil uji model fixed effect, variabel government expenditure didapatkan bahwa pengeluaran pemerintah berpengaruh positif signifikan terhadap pertumbuhan ekonomi di 10 negara Anggota OKI. Hasil uji model fixed effect ditemukan hasil yang cukup menarik bahwa pertumbuhan penduduk berpengaruh negative signifikan terhadap pertumbuhan ekonomi di 10 negara Anggota OKI. Model fixed effect, variabel human development index didapatkan bahwa human development index berpengaruh positif signifikan terhadap pertumbuhan ekonomi di 10 negara Anggota OKI. Hal ini menjelaskan bahwa semakin tinggi sumber daya manusia maka akan semakin baik bagi pertumbuhan ekonomi. Berdasarkan hasil uji model fixed effect, diketahui bahwa angkatan kerja berpengaruh negatif signifikan terhadap pertumbuhan ekonomi di 10 negara Anggota OKI. Hasil ini mengindikasikan bahwa ketika angkatan kerja tinggi namun tidak tersedianya lapangan pekerjaan yang mencukupi akan menurunkan pertumbuhan ekonomi. Model fixed effect bahwa variabel indeks demokrasi tidak berpengaruh signifikan terhadap pertumbuhan ekonomi di 10 negara Anggota OKI.

\section{DAFTAR PUSTAKA}

Andreas Lako. (2006). Kepemimpinan dan Kinerja Organisasi, Isu, Teori dan Solusi, Cetakan Pertama, Yogyakarta : Amara Books

Cabeza-García, L., Brio, E. B. 2018. "Gender Factors and Inclusive Economic Growth: The Silent Revolution.” Sustainability, 1-14.

Drury, A. Cooper, Jonathan Krieckhaus, and Michael Lusztig. 2006. "Corruption, Democracy, and Economic Growth.” International Political Science Review 27 (2): 121-36. https://doi.org/10.1177/0192512106061423.

Elistia, Elistia, and Barlia Annis Syahzuni. 2018. "The Correlation of the Human Development Index (Hdi) Towards Economic Growth (Gdp Per Capita) in 10 Asean Member Countries." Jhss (Journal of Humanities and Social Studies) 2 (2): 40-46. https://doi.org/10.33751/jhss.v2i2.949.

George N, Mankiw. 2003. Makro Ekonomi. Jakarta: Erlangga.

Jordaan, Andre C., and Joel Hinaunye Eita. 2007. "Export and Economic Growth in Namibia: A Granger Causality Analysis." South African Journal of Economics 75 (3): 540-47. https://doi.org/10.1111/j.1813-6982.2007.00132.x. 
Khan, M. A. 2020. “Testing Malthusian's AndKremer's Population Theories." International Journal of Social Economics Vol. 47 No: 523-38.

Loizides, John, and George Vamvoukas. 2005. "Government Expenditure and Economic Growth: Evidence from Trivariate Causality Testing." Journal of Applied Economics 8 (1): 125-52. https://doi.org/10.1080/15140326.2005.12040621.

Malthus. 1798. On Population. Singapore Medical Journal. Vol. 141. https://doi.org/10.2307/2569106.

Malthus, Thomas Robert, Shannon C. Stimson, Niall O'Flaherty, Deborah Valenze, E. A. Wrigley, Kenneth Binmore, and Karen O'Brien. 2018. An Essay on the Principle of Population: The 1803 Edition. An Essay on the Principle of Population: The 1803 Edition.

North, Douglass C.North, Douglass C. 1964. Location Theory and Regional Economic Growth. Cambridge: The M.I.T. Press.

OIC E CONOMIC O UTLOOK 2017 Industrial Development for Structural. 2017.

Safitri, Aisyah, and Ariusni. 2019. "Pengaruh Kinerja Keuangan Daerah, Tingkat Partisipasi Angkatan Kerja, Dan Inflasi Terhadap Pertumbuhan Ekonomi Di Sumatera Barat.” Jurnal Kajian Ekonomi Dan Pembangunan 1 (2): 351-64.

Sekaran, Uma dan Roger Bougi. 2017. Metode Penelitian Untuk Bisnis: Pendekatan Pengembangan-Keahlian, Edisi 6, Buku 1, Cetakan Kedua. Jakarta Selatan: Salemba Empat.

Seymour, Lipset. 1963. Political Man: Social Bases Of Politics. New York: Anchor.

Sukirno, Sadono. 2006. Makroekonomi: Teori Pengantar (Edisi Ke Tiga). Jakarta: Rajawali Press.

Wibowo, Muhammad Ghafur. 2020. "Good Public Governance in Islamic Perspective: An Analysis on the World Governance Indicator in OIC Member Countries." Ihtifaz: Journal of Islamic Economics, Finance, and Banking 3 (1): 51. https://doi.org/10.12928/ijiefb.v3i1.1718.

Yakubu, Muhammad M., and Benedict N. Akanegbu2 and Jelilov G. 2018. "Female Labour Participation And Economic Growth In Nigeria." Ilorin Journal of Economic Policy 5 (5): 1-11. 